\title{
THE REVIEW OF THE RUSSIAN FEDERATION BASE OF THE BUDGETARY PROCESS IN JANUARY 2016
}

\section{M.Goldin}

In January 2016, in the budgetary process the following events took place: Measures Aimed at Implementation of the Federal Law on the 2016 Federal Budget and the Rules of Placement of Federal Budget Funds in Deposits with the Vnesheconombank were approved by the Resolution of the Government of the Russian Federation.

By Resolution No.1456 of 28 December 2015 of the Government of the Russian Federation, Measures Aimed at Implementation of the Federal Law on the 2016 Federal Budget were approved (hereinafter, Resolution No.1456).

In particular, by Resolution No.1456 the procedure for amending the overall federal budget expenditure items for 2016 was established.

So, in 2016 amendment of the overall budget items is carried out by the Ministry of Finance of the Russian Federation on the basis of proposals envisaging higher budget allocations and budget commitment limits - submitted by main administrators of federal budget funds to the Ministry of Finance of the Russian Federation before 25 February 2016:

a) as regards payment of state contracts on delivery of goods, fulfilment of jobs and rendering of services which are subject in accordance with the terms of those contracts to payment in 2015 - in the volume which does not exceed the outstanding budget commitment limits as of the beginning of 2016 for fulfilment of the above state contracts;

b) as regards provision to budgets of constituent entities of the Russian Federation of subsidies and other target inter-budgetary transfers which in 2015 were allocated within the limits of the amount needed for payment of liabilities of recipients of budget funds of a constituent entity of the Russian Federation whose source of funding is the above inter-budgetary transfers within the volumes of target budget commitment limits outstanding in 2015.

In addition to the above, by Resolution No.1456 the procedure for making advance payments in favor of providers under state contracts (contractors and performers) and volumes thereof were determined.

By general rule, the amount of an advance payment in entering into agreements (state contracts) on delivery of goods, fulfilment of jobs and rendering of services is determined in the amount of maximum $30 \%$ of the sum of the agreement (a state contract), but not in excess of budget commitment limits under the relevant code of the RF budget classification.

An advance payment in the amount of over $30 \%$ to $80 \%$ of the sum of the agreement (a state contract), but not in excess of budget commitment limits under a relevant code of the RF budget classification can be envisaged under agreements (state contracts) on R\&D aimed at import substitution of technological products with inclusion in the above agreements (state contracts) (except for contracts (state contracts) which fulfilment is subject to monitoring by a bank in accordance with the legislation of the Russian Federation on the concrete system of purchasing of goods, jobs and services for state and municipal needs) a condition to transfer advance payments to accounts 
opened by territorial offices of the Federal Treasury with offices of the Central Bank of Russia for keeping record of operations with funds of entities which are not budget process participants, as well as in case of receipt of a confirmation of the above agreements (state contracts) from a federal executive authority carrying out development of the state policy and regulation in the field of foreign and internal trade to the effect that such an agreement (state contract) complies with goals of import substitution of technological products prior to using competitive methods of determination of providers (contractors and performers) or making purchases from a sole provider.

An advance payment of up to $100 \%$ of the sum of the agreement (state contract), but not in excess of budget commitment limits under a relevant code of RF budget classification can be envisaged by agreements (state contracts) on rendering of communication services, subscription to publications, advanced training, occupational retraining, participation in scientific, methodological, academic and research and other conferences, state due diligence of design documentation and outputs of engineering surveys and verification of accuracy of the estimated cost of capital construction projects and financial provision of building, reconstruction and technical re-equipment thereof which are planned to be fulfilled at the expense of federal budget funds or other.

By Resolution No.1495 of 30 December 2015 of the Government of the Russian Federation, the Rules of Placement of Federal Budget Funds in Deposits with the Bank for Development of Foreign Economic Affairs, a State Corporation (the Vnesheconombank) (hereinafter, the Rules) were approved.

The Rules establish the procedure for placing by the Federal Treasury on the basis of individual decisions of the Government of the Russian Federation of federal budget funds in deposits with the Bank for Development of Foreign Economic Affairs, a State Corporation (the Vneshekonombank). By the above resolutions of the Government of the Russian Federation, the following terms of placement of funds are determined:

a) currency of the deposit;

b) amount of the deposit;

c) term of the deposit;

d) interest rate on deposit.

Federal budget funds are deposited with the Vnesheconombank on the basis of an agreement concluded by the Vnesheconombank with the Federal Treasury. It is to be noted that the terms of the agreement are determined by the Federal Treasury by agreement with the Ministry of Finance of the Russian Federation. The terms of the agreement should provide for the following:

a) payment of interests on placement of funds upon maturity of the deposit;

b) early return of funds is feasible on the initiative of the Vnesheconombank with interests paid on the actual period of funds in the deposit;

c) One-time extension of the period of a deposit agreement (deposit) is admissible on the terms of the original agreement. 